\title{
X-ray Photoelectron Spectroscopy (XPS) Analysis of Undoped ZnO and ZnO:Er Thin Films
}

\author{
Iwan Sugihartono*), Esmar Budi, and Agus Setyo Budi \\ Jurusan Fisika, FMIPA Universitas Negeri Jakarta \\ *)Email: isugihar@hotmail.com
}

\begin{abstract}
Undoped $\mathrm{ZnO}$ and $\mathrm{ZnO}: \mathrm{Er}$ thin films were deposited on $p$-type $\mathrm{Si}$ substrates by ultrasonic spray pyrolisis (USP). Undoped and $\mathrm{ZnO}$ :Er thin films have been analyzed by using X-ray Photoelectron Spectroscopy (XPS). The results show that the XPS spectrum has two Er peak at $\sim 157 \mathrm{eV}$ and $\sim 168 \mathrm{eV}$. The XPS Zn 2p spectrum of undoped $\mathrm{ZnO}$ and $\mathrm{ZnO}$ :Er thin films have binding energy for $\mathrm{Zn} 2 \mathrm{p}_{3 / 2}(\sim$ $1021 \mathrm{eV})$ and $\mathrm{Zn} 2 \mathrm{p}_{1 / 2}(\sim 1045 \mathrm{eV})$ were found no shift in binding energy after the incorporation of Er. Meanwhile, after Er incorporates into $\mathrm{ZnO}$, the $\mathrm{O} 1 \mathrm{~s}$ spectrum is composed two peak of binding energy (BE) at $\sim 530.5 \mathrm{eV}$ and the shoulder about $532.5 \mathrm{eV}$.
\end{abstract}

Keywords: $\mathrm{ZnO}$ thin films, $\mathrm{ZnO}: \mathrm{Er}, \mathrm{XPS}$, binding energy

\section{INTRODUCTION}

$\mathrm{ZnO}$ is a material semiconductor which has wide band gap energy $3.34 \mathrm{eV}$ and large exciton binding energy $60 \mathrm{meV}$ (Teke, et al, 2004). Nevertheless, $\mathrm{ZnO}$ has asymetry problem. It is regarding with the existence of native defects which make $\mathrm{ZnO}$ very difficult to be n-type semiconductor. Due to its character, many effort to elaborate $\mathrm{ZnO}$ properties has been reported.

XPS is one of the most powerful surface analytical techniques. Basic principle of XPS can be explained that the photon energy ( $\mathrm{x}$-ray photon) in and absorbed by atom in molecular or solid hence leading ionization and the emission of core electrons in certain shell (Chen, et al, 2000). Therefore, determination of the chemical state of elements on the surface is of great theoretical and practical interest. The chemical shifts of the binding energy values of the core electron lines represent the most easily accessible and interpretable information on the changes in the chemical state.

In this paper, undoped and $\mathrm{ZnO}: \mathrm{Er}$ thin films have been grown by USP tecnhnique. Furthermore, the films were characterized by Xray Photoelectron Spectroscopy (XPS).

\section{EXPERIMENTAL DESIGN}

Undoped $\mathrm{ZnO}$ and $\mathrm{ZnO}: \mathrm{Er}$ thin films were deposited on $p$-type $\mathrm{Si}$ substrates with a carrier concentration of $\sim 10^{19} \mathrm{~cm}^{-3}$ by ultrasonic spray pyrolisis (USP) (Iwan, et al, 2012). Zinc acetate dehydrate $\left[\mathrm{Zn}\left(\mathrm{CH}_{3} \mathrm{COO}\right)_{2} .2 \mathrm{H}_{2} \mathrm{O}\right]$ and erbium (III) acetate hydrate $\left[\operatorname{Er}\left(\mathrm{C}_{2} \mathrm{H}_{3}\right) \cdot \mathrm{xH}_{2} \mathrm{O}\right]$ were chosen as host and dopant precursors, respectively. The zinc acetate $(0.02 \mathrm{~mol} / \mathrm{ml})$ was mixed with the erbium (III) acetate hydrate ( $1 \mathrm{wt} \%, 4 \mathrm{wt} \%$ and $8 \mathrm{wt} \%$ ) and diluted in de-ionized water (Iwan, et al, 2012). The aerosol of the precursor solution was generated by a commercial ultrasonic nebulizer (frequency of $1.65 \mathrm{MHz}$ ), and injected onto a $\mathrm{Si}$ substrate heated at $450^{\circ} \mathrm{C}$. Furthermore, the surface of $\mathrm{ZnO}: \mathrm{Er}$ films has been etched by $\mathrm{Ar}^{+}$ ion prior to the XPS measurement.

\section{RESULTS AND DISCUSSION}

X-ray photoelectron spectroscopy (XPS) was employed to identify the chemical states of the Er in $\mathrm{ZnO}$ :Er films. XPS study of the Er (4d) proves the existence of $\mathrm{Er}$ in all the $\mathrm{ZnO}$ : Er films (Iwan, et al, 2012), as shown in Figure 1. The atomic concentration of $\mathrm{Er}$ in $\mathrm{ZnO}: \mathrm{Er}$ is determined quantitavely use area under peak as intensity divided by factor which relates with atomic cross section. Yet, $\mathrm{ZnO}: \operatorname{Er}(1 \mathrm{wt} \%), \mathrm{ZnO}: \operatorname{Er}(4 \mathrm{wt} \%)$, and $\mathrm{ZnO}: \operatorname{Er}(8 \mathrm{wt} \%)$ films are estimated to be $0.72 \mathrm{at} \%$, $1.12 \mathrm{at} \%$, and $1.17 \mathrm{at} \%$, respectively. The XPS spectrum shows two Er peak at $\sim 157 \mathrm{eV}$ and $\sim 168$ Ev (Iwan, et al, 2012). The peak at $\sim 157 \mathrm{eV}$ indicates due to Auger electron effect (Netzer, et al, 1981). Furthermore, with the increase of $\mathrm{Er}$ atomic concentration $(1.17 \mathrm{at} \%)$, the $4 \mathrm{~d}_{5 / 2}$ state peak at $\sim 168 \mathrm{eV}$ could be clearly observed.

Figure 2 shows the XPS Zn 2 p spectrum of undoped $\mathrm{ZnO}$ and $\mathrm{ZnO}$ : $\mathrm{Er}$ thin films. The $\mathrm{Zn} 2 \mathrm{p}_{3 / 2}$ $(\sim 1021 \mathrm{eV})$ and $\mathrm{Zn} 2 \mathrm{p}_{1 / 2}(\sim 1045 \mathrm{eV})$ were found no shift in binding energy after the incorporation of Er. Those two peaks indicate that there is no shift binding energy of $\mathrm{Zn} 2 \mathrm{p}$ and the chemical state of $\mathrm{Zn}$ remains the same after incorporation of Er. On the other hand, the formation of $\mathrm{O} 1 \mathrm{~s}$ spectrum before $\mathrm{Er}$ incorporate into $\mathrm{ZnO}$ has single peak at $\sim 532 \mathrm{eV}$. 


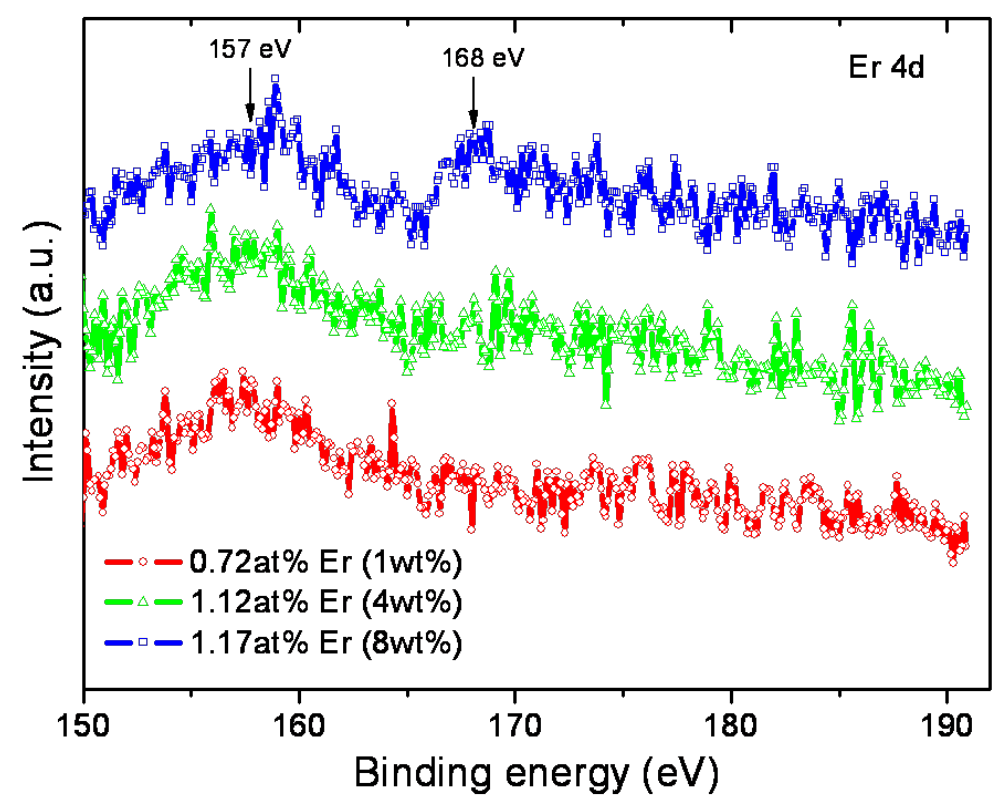

Figure 1. Binding energy of Er 4d (Iwan, et al., 2012)

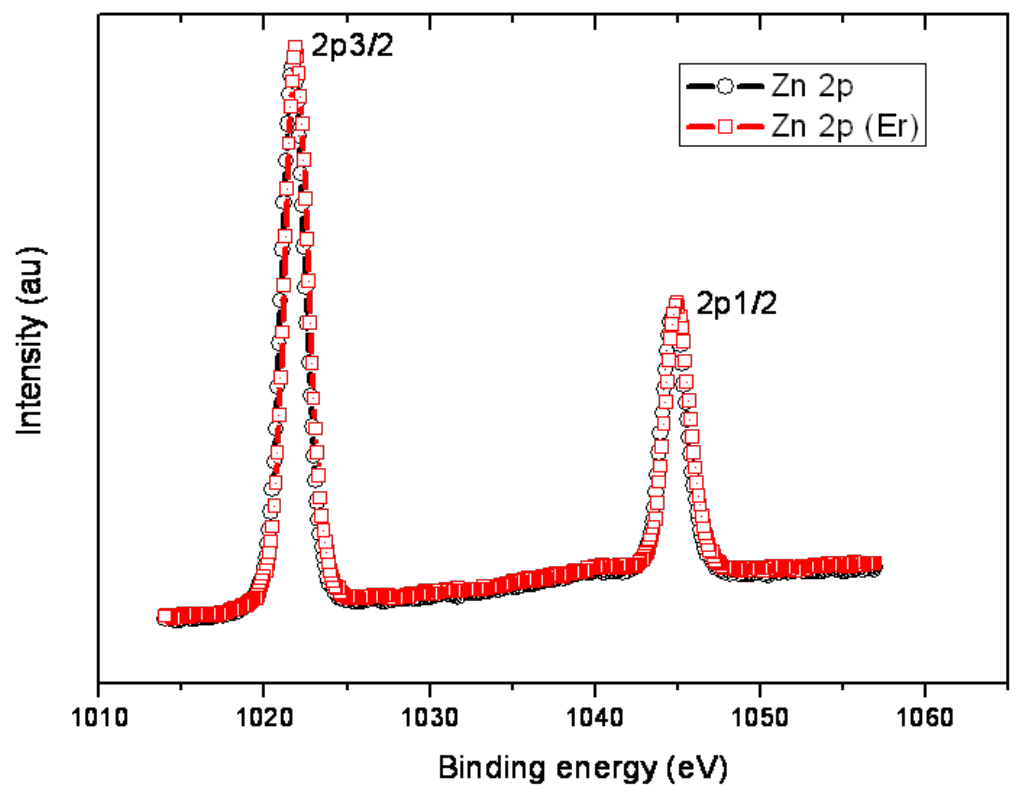

Figure 2. Binding energy of $\mathrm{Zn} 2 \mathrm{p}$ 


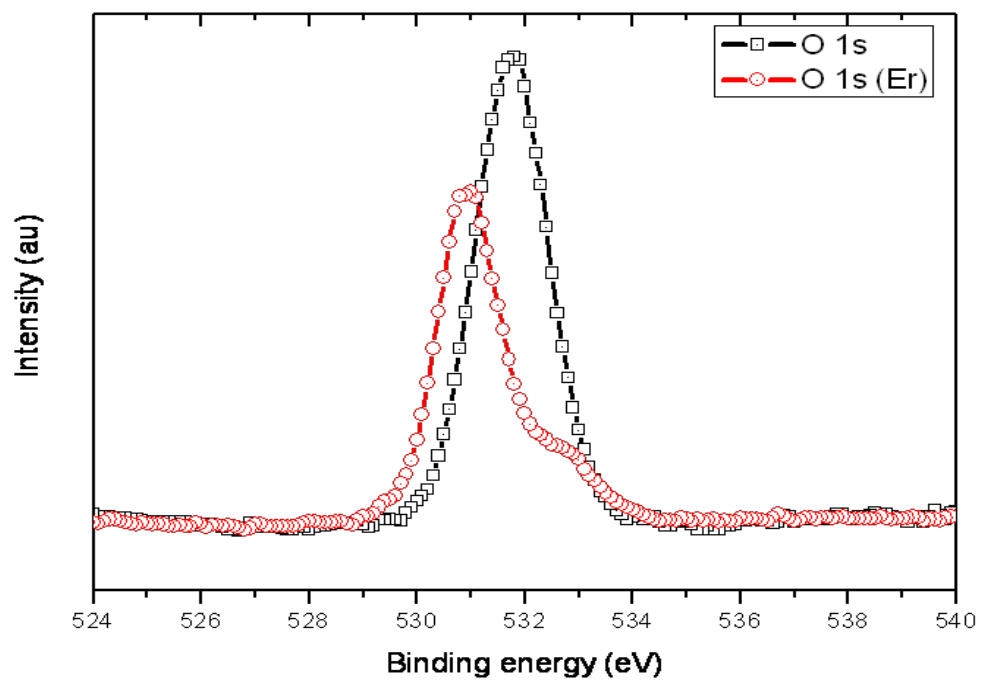

Figure 3. Binding energy of $\mathrm{O} 1 \mathrm{~s}$

Figure 3 shows the $\mathrm{O}$ 1s spectrum after $\mathrm{Er}$ incorporates into $\mathrm{ZnO}$. The $\mathrm{O}$ 1s spectrum is composed two peak of binding energy (BE) at $\sim 530.5 \mathrm{eV}$ and the shoulder about $532.5 \mathrm{eV}$.

The appearance of shoulder indicated there is a residual oxygen on the thin film surface or oxidized Er. ${ }^{2}$ Moreover, the spectrum at the peak $\sim 1021 \mathrm{eV}$ and $\mathrm{O} 1 \mathrm{~s}$ spectrum at $\sim 530.5 \mathrm{eV}$ corresponds to the chemical bonding structure of $\mathrm{ZnO}$ thin film (Shuji, et al, 2000; Islam, et al, 1996).

\section{CONCLUSIONS}

In conclusions, the XPS spectrum shows two Er peak at $\sim 157 \mathrm{eV}$ and $\sim 168 \mathrm{eV}$. The XPS Zn $2 \mathrm{p}$ spectrum of undoped $\mathrm{ZnO}$ and $\mathrm{ZnO}: \mathrm{Er}$ thin films have binding energy for $\mathrm{Zn} 2 \mathrm{p}_{3 / 2}(\sim 1021 \mathrm{eV})$ and $\mathrm{Zn} 2 \mathrm{p}_{1 / 2}(\sim 1045 \mathrm{eV})$ were found no shift in binding energy after the incorporation of Er. Meanwhile, after Er incorporates into $\mathrm{ZnO}$, the $\mathrm{O}$ 1s spectrum is composed two peak of binding energy (BE) at $\sim 530.5 \mathrm{eV}$ and the shoulder about $532.5 \mathrm{eV}$.

\section{REFERENCES}

Chen, M., X. Wang, Y.H. Yu, Z.L Pei, X.D Bai, C Sun, R.F Huang, L.S Wen, Applied Surface Science.158, 134-140 (2000).

Islam, M.N., T. B. Ghosh, K. L. Chopra, and H. N. Acharya, Thin Solid Films 280, 20-25 (1996).

Iwan, S., S. Bambang, J. L. Zhao, S. T. Tan, X. W. Sun, G.Q. Lo, H. M. Fan, L. Sun, S. Zhang., Physica B: Condensed Matter. 407, 2721-2724 (2012).

Netzer, F.P., E. Bertel, and J. A. D. Matthew, J. Phys. C: Solid State Phsyics 14, 1891 (1981).

Shuji, K., K. Tooru, M. Takitaro, Z. Xinwei, I. Hideo, and A. Yoshinobu, Journal of Applied Physics 88, 7129-7136 (2000).

Teke, A., Ü. Özgür, S. DoÄŸan, X. Gu, H. Morkoç, B. Nemeth, J. Nause, and H. O. Everitt, Physical Review B 70, 195207 (2004). 